\author{
Maria Elżbieta JASTRZĘBSKA, PhD, Professor of the University of Gdańsk \\ Faculty of Management, University of Gdańsk \\ e-mail: maria.jastrzebska@ug.edu.pl \\ ORCID: 0000-0002-0027-930X
}

DOI: $10.15290 /$ oes.2020.03.101.01

\title{
TRANSPARENCY OF INFORMATION CONTAINED IN THE STATE BUDGET FROM THE VIEW OF UTILITY FOR THE CITIZEN ${ }^{1}$
}

\begin{abstract}
Summary
Purpose - The purpose of the article is to assess the transparency of information contained in the state budget from the point of view of usefulness for the citizen and to recommend actions to increase the transparency of information in this regard.

Methods - Descriptive analysis and deductive and inductive reasoning were used.

Research description - The essence of fiscal transparency in the context of social responsibility of the government was discussed. The scope of information included in: the multi-year financial state finance, the budget act, the report on the implementation of the state budget, the analysis of the implementation of the state budget was analyzed. The assessment of information in the above-mentioned scope was carried out from the point of view of usefulness for the citizen and the flow of information between the government and citizens about public funds collected and allocated by the state budget. Finally, recommendations were made for actions to be taken to increase the transparency of information contained in the state budget.

Results - The transparency of the information contained in the state budget (at the stage of its planning, adoption, implementation, reporting and controlling budget implementation) is very limited from the point of view of its usefulness for the citizen. It is necessary to take specific actions to increase the transparency of information contained in the state budget from the point of view of its usefulness for the citizen.

Originality / value - the literature on the subject lacks publications devoted to the issue of transparency of the state budget in our country. The article addresses this research problem by assessing the content of information published by the government in the state budget as the basic public fund from the point of view of the usefulness of this information for the citizen.
\end{abstract}

Keywords: fiscal transparency, state budget, civil society

JEL Classification: H11, H30, H61

${ }^{1}$ Article received on 17 March 2020, accepted on 20 April 2020. 


\section{Introduction}

As the standard of living increases, the demand for public services also increases, which entails the need to exercise effective control over the activities of the government and public finance sector entities (PFSE). In addition, the increase in the level of education creates a need for the increase in the level and quality of communication between public authorities and society. Specifically, detailed information is required about government activities within the state budget, but also outside of it. It is primarily about providing citizens with the opportunity to learn the budget procedure and to access budget documents in such a way that they can influence decisions in the field of fiscal policy and hold the government responsible for the effects of public finance management. Therefore, the quality of this information, its correct flow and understanding by the recipients is very important. Fiscal transparency makes it possible to assess the real situation of public finance and the level of implementation of economic and social policy objectives. Ensuring fiscal transparency reduces fiscal risk and corruption and supports public acceptance of fiscal reforms. Therefore, a special role is played by the social responsibility of the government, which prepares and implements the state budget for collecting and spending a significant part of public funds in each country. The purpose of the article is to assess the transparency of information contained in the state budget of our country from the point of view of usefulness for the citizen and to recommend actions to increase the transparency of information in this regard.

\section{The essence of fiscal transparency in the context of government social responsibility}

The government is responsible to its own citizens for what it does and how it does it. This responsibility means that the policies and strategies developed by the government should reflect the priorities and needs of citizens and the government should report on what it did to implement them. In turn, citizens responsible for bringing the government to justice should participate in public life, monitor government activities, comment on its policies and strategies, and question them when something goes wrong [Jabłoński, 2018, pp. 39-40]. The social responsibility of the government is understood as the obligation to periodically evaluate government's actions by the citizens in terms of the effectiveness of social and economic implementation as a result of the activities of PFSE, using financial and non-financial resources entrusted by the society [Kostrzewa, 2011a, p. 239].

Transparency of government activities is an important condition for macroeconomic sustainability of public finance. It is conducive to strengthening the democratic order and strengthening public control over the activities of public authorities, as well as increasing the efficiency and effectiveness of collecting public revenues and implementing public expenditures [Alt et al., 2006, pp. 2-3]. 
The transparency of government activities is integrally linked to fiscal transparency defined as openness to the public in terms of information on: the structure and tasks of the government; goals and assumptions of fiscal policy and conditions of their implementation; planned and current accounts of the public finance sector. This requires access to reliable, comprehensive, timely, understandable information about government activities, enabling international comparisons, so that citizens (electorate) and financial markets can assess the financial situation of the state and the costs and benefits of government activities as well as the current and future socio-economic implications of these activities [Kopits, Craig, 1988, p. 1]. In the national literature on the subject there is a concept of transparency of public finance understood as a situation in which rules for managing public funds are clearly defined, and the system for collecting, processing and sharing data on the state of public finance allows for obtaining a full, reliable and understandable picture of the financial situation of the public finance sector as a whole and its individual subsectors, and the impact of their functioning on the national economy [Misiag, Niedzielski, 2001, p. 5]. Thus, the transparency of public finance guarantees that the information provided is useful, legible, reliable, complete, timely and comparable. The Public Finance Act precisely defines what information on public finance must be disclosed to the public and what actions must be taken in public but does not specify in what form this data should be made public [Sawulski, 2015, p. 4].

The concept of fiscal transparency is narrower than the concept of transparency of all government activities and is used to refer to the impact of the revenue and expenditure side of the state budget on the socio-economic situation in the country. As part of fiscal transparency, we can talk about budget transparency, which refers to the scope and ease of citizens' access to the information on budgetary revenues and expenditures and budget results. Therefore, the budget should be transparent, available, precise and budget information should be provided in a timely manner so that citizens can effectively influence the formulation of budget policy and the reallocation of resources [Malinowska-Misiag, 2016, p. 12].

Accounting, as an element of control and protection of public property and ensuring management staff's responsibility to the society, provides information on the financial and property situation and financial results of PFSE in financial and budgetary reports. An efficient accounting system is a condition for budget implementation as planned and for maintaining public finance discipline. It is also important to define transparent relations between individual PFS subsectors and to report them. The condition for the efficient functioning of the accounting system is the development of external and internal forms of control and audit in order to maintain data reliability and adherence to public finance discipline [Nowak, 1998, pp. 9-12].

The financial and budgetary statements should provide useful information to external recipients. Useful information has certain qualitative features, i.e. usefulness (relevance) and honest presentation of reality (credibility). Additional beneficial features include comparability, verifiability, timeliness and comprehensibility of information. The quality of financial and budgetary reports is understood primarily as their information usefulness. The information needs of individual users of these re- 
ports are diverse, and their preparation and presentation should take this fact into account [Kozłowska, 2018, pp. 247, 249].

\section{The scope of information included in the multi-annual financial plan of the state, the budget act, the report on the implementation of the state budget, the analysis of the implementation of the state budget}

Information on the financial and property situation of the entire PFS in our country is very limited. Over 45 thousand units belong to PFS [www 1], and the scope of data presented in their financial statements is not consistent. Detailed information on the implementation of financial plans is published only for the state budget, the budget of European funds, local government budgets and there is limited information on the finance of state earmarked funds, executive agencies, budgetary economy institutions, state legal persons. A summary of PFS's revenues, expenditures, budget results is included in the report on the implementation of the state budget. However, the analysis in this respect is complicated by numerous financial flows within PFSE, with information on these flows usually not available or requiring specific knowledge to be found.

The structure of PFS and the mechanism for financing public tasks assigned the state budget the role of a public fund transferring a significant part of public funds to PFSE (local government units, state-owned special purpose funds, executive agencies...). In the years 2014-2018, public revenues included in the Budget Act constituted about $73 \%$ of total PFS `s revenues, and public expenditures about $58-61 \%$ of total SFP's expenditures, with state budget revenues only over $41-44 \%$ of total PFS`s revenues, and budget expenditures over 22-20\% of total PFS`s expenditures (table 1). So in practice, more importance is attached to the state budget than it results from its share in public revenues and expenditures. The public debate on public finance is dominated by the discussion on the budget act, and, to a lesser extent, on the implementation of the state budget and the assessment of the implementation of the state budget.

The instrument of the government's accountability to the public are published financial plans (the Multi-year State Financial Plan, the Budget Act) and summary reports (the report on the implementation of the state budget and the report on the state of the property of the Treasury). The layout of the Budget Act and explanatory materials to the Draft Budget Act, as well as reports on the implementation of the state budget and a number of attachments to this report do not meet the basic requirements of public finance transparency (table 2). 
TABLE 1

Public revenues and expenditures included in the Budget Act in comparison with total public revenues and expenditures in 2015-2018 in \% after consolidation

\begin{tabular}{|l|c|c|c|c|c|}
\hline \multicolumn{7}{|c|}{ REAR } & $\begin{array}{c}\text { PFS`s } \\
\text { revenues } \\
\text { in PLN } \\
\text { billion } \\
\text { Yevenues } \\
\text { included in } \\
\text { the budget } \\
\text { act } \\
\text { in PLN } \\
\text { billion }\end{array}$ & $\begin{array}{c}\text { State } \\
\text { budget } \\
\text { revenues } \\
\text { in PLN } \\
\text { billion }\end{array}$ & $\begin{array}{c}\text { Share of PFS`s } \\
\text { revenues in- } \\
\text { cluded in the } \\
\text { Budget Act to } \\
\text { total PFS`s } \\
\text { revenues } \\
\text { in \% }\end{array}$ & $\begin{array}{c}\text { Share of state } \\
\text { budget } \\
\text { revenues } \\
\text { in total PFS`s } \\
\text { revenues } \\
\text { in \% }\end{array}$ \\
\hline 2014 & 668.9 & 489.0 & 277.2 & 73.1 & 41.4 \\
\hline 2015 & 684.7 & 499.4 & 284.4 & 73.0 & 41.5 \\
\hline 2016 & 698.7 & 507.4 & 310.1 & 72.6 & 44.4 \\
\hline 2017 & 772.9 & 569.5 & 345.9 & 73.7 & 44.6 \\
\hline 2018 & 861.6 & 629.5 & 375.7 & 73.1 & 43.6 \\
\hline & & \multicolumn{7}{|c|}{ EXPENDITURES } & & \\
\hline 2014 & 716.9 & 438.0 & 152.7 & 61.1 & 21.3 \\
\hline 2015 & 731.9 & 446.7 & 154.2 & 61.0 & 21.0 \\
\hline 2016 & 747.9 & 454.6 & 161.7 & 57.5 & 21.6 \\
\hline 2017 & 790.3 & 466.1 & 176.7 & 59.0 & 22.4 \\
\hline 2018 & 861.2 & 499.6 & 175.7 & 58.0 & 20.4 \\
\hline
\end{tabular}

Source: [www 2].

The information provided in the aforementioned budget documents is incomprehensible to a citizen who does not have specialist knowledge in the field of public finance. These documents primarily contain many tables with data in a budget classification system. The question also arises as to whether the representatives of citizens elected in the elections to the Sejm and Senate understand what they are discussing (the budget act, the budget discharge). The Chancellery of the Sejm and the Chancellery of the Senate support deputies and senators with expert opinions on the draft of the entire Budget Act or individual parts of it (however, they are not always available to the public). It should also be noted that multiannual planning is not based on budget reporting. It is unclear whether and how the amounts allocated to finance the tasks reported in the annual reports contribute to the implementation of the tasks included in the multiannual plans, since the reports on the implementation of the most important strategies and programs are inconsistent with the annual budget reports [Zapewnienie jawności i przejryystości ..., 2015, p. 14]. 
TABLE 2

The scope and number of pages of documents related to the budget procedure at the state budget level made publicly available in years 2018, 2019, 2020

\begin{tabular}{|c|c|c|c|c|}
\hline $\begin{array}{l}\text { Multiannual State } \\
\text { Financial Plan } \\
\text { for the years } \\
2019-2022 \\
\text { as the basis for } \\
\text { Draft Budget Act } \\
\text { for } 2020\end{array}$ & $\begin{array}{l}\text { Draft Budget } \\
\text { Act for } 2020\end{array}$ & $\begin{array}{l}\text { Budget Act } \\
\text { for } 2019\end{array}$ & $\begin{array}{l}\text { Report } \\
\text { on the imple- } \\
\text { mentation of the } \\
\text { state budget } \\
\text { for } 2018\end{array}$ & $\begin{array}{l}\text { Analysis of the } \\
\text { implementation } \\
\text { of the state } \\
\text { budget for } 2018\end{array}$ \\
\hline $\begin{array}{l}\text { Assessment of the } \\
\text { current economic } \\
\text { situation and fore- } \\
\text { cast }\end{array}$ & $\begin{array}{l}\text { The text part of } \\
\text { the draft budget } \\
\text { act }-12 \text { pages }\end{array}$ & $\begin{array}{l}\text { The text part } \\
\text { of the draft } \\
\text { budget act } \\
-8 \text { pages }\end{array}$ & $\begin{array}{l}\text { Discussion on the } \\
\text { report on the } \\
\text { implementation } \\
\text { of the state } \\
\text { budget - } 346 \\
\text { pages }\end{array}$ & $\begin{array}{l}\text { The most im- } \\
\text { portant findings } \\
\text { and conclusions } \\
\text { of the Supreme } \\
\text { Audit Office }\end{array}$ \\
\hline $\begin{array}{l}\text { General government } \\
\text { balance and debt }\end{array}$ & $\begin{array}{l}25 \text { attachments } \\
-608 \text { pages } \\
\text { of tables ** }\end{array}$ & $\begin{array}{l}18 \text { attachments } \\
\text { to the text part } \\
\text { include } 587 \\
\text { pages of tables } \\
* *\end{array}$ & $\begin{array}{l}\text { Volume I Report } \\
-814 \text { pages of } \\
\text { tables } * *\end{array}$ & $\begin{array}{l}\text { Evaluation of } \\
\text { the draft budget } \\
\text { act and the } \\
\text { most important } \\
\text { legal acts related } \\
\text { to the budget } \\
\text { act }\end{array}$ \\
\hline $\begin{array}{l}\text { Sensitivity analysis } \\
\text { and comparison } \\
\text { with the previous } \\
\text { Convergence } \\
\text { Program update }\end{array}$ & $\begin{array}{l}\text { The justification } \\
\text { for the Budget } \\
\text { Act }-239 \text { pages }\end{array}$ & $\begin{array}{l}\text { The justifica- } \\
\text { tion for the } \\
\text { Budget Act } \\
\text { shall not be } \\
\text { included }\end{array}$ & $\begin{array}{l}\text { Volume II Report } \\
-279 \text { pages of } \\
\text { tables - infor- } \\
\text { mation on } \\
\text { voivodships' } \\
\text { budgets }\end{array}$ & $\begin{array}{l}\text { Assessment } \\
\text { of the imple- } \\
\text { mentation of } \\
\text { the Budget Act }\end{array}$ \\
\hline $\begin{array}{l}\text { Long-term } \\
\text { sustainability } \\
\text { of public finance }\end{array}$ & $\begin{array}{l}\text { Information } \\
\text { on planned } \\
\text { local govern- } \\
\text { ment budgets is } \\
\text { not included }\end{array}$ & $\begin{array}{l}\text { Information on } \\
\text { planned local } \\
\text { government } \\
\text { budgets is not } \\
\text { included }\end{array}$ & $\begin{array}{l}\text { Information on } \\
\text { the implemen- } \\
\text { tation of local } \\
\text { government } \\
\text { budgets - } 188 \\
\text { pages - infor- } \\
\text { mation on rev- } \\
\text { enues, expend- } \\
\text { itures, budget } \\
\text { results, liabilities, } \\
\text { receivables } \\
\text { The attachments } \\
\text { to this infor- } \\
\text { mation - } 176 \\
\text { pages of tables }\end{array}$ & $\begin{array}{l}\text { Assessment } \\
\text { of accounting } \\
\text { books and } \\
\text { opinion on } \\
\text { budget reports }\end{array}$ \\
\hline
\end{tabular}




\begin{tabular}{|l|l|l|l|l|}
\hline $\begin{array}{l}\text { National budgetary } \\
\text { frameworks }\end{array}$ & $\begin{array}{l}\text { The consoli- } \\
\text { dated expend- } \\
\text { itures plan for } \\
2020 \text { and the } \\
\text { next two years - } \\
177 \text { pages } \\
\text { (descriptive part } \\
-143 \text { pages and } \\
\text { attachments } \\
34 \text { pages) }\end{array}$ & $\begin{array}{l}\text { The consoli- } \\
\text { dated plan of } \\
\text { state budget } \\
\text { expenditures is } \\
\text { not published }\end{array}$ & $\begin{array}{l}\text { Information on } \\
\text { the implemen- } \\
\text { tation of expen- } \\
\text { ditures in the task } \\
\text { system - 212 } \\
\text { pages (descriptive } \\
\text { part - 193 pages } \\
\text { and attachments } \\
-19 \text { pages) }\end{array}$ & $\begin{array}{l}\text { Settlements of } \\
\text { the state budget } \\
\text { and the budget } \\
\text { of European } \\
\text { funds in a task } \\
\text { system } \\
\text { Treasury debt } \\
\text { and public debt } \\
\text { Revenues and } \\
\text { expenditures } \\
\text { of PFS } \\
\text { Implementation } \\
\text { of monetary } \\
\text { policy assump- } \\
\text { tions }\end{array}$ \\
\hline Total 92 pages & $\begin{array}{l}\text { Total 1 036 } \\
\text { pages }\end{array}$ & $\begin{array}{l}\text { Total 595 } \\
\text { pages }\end{array}$ & $\begin{array}{l}\text { Total 2 015 } \\
\text { pages }\end{array}$ & $\begin{array}{l}\text { Total 416 } \\
\text { pages }\end{array}$ \\
\hline
\end{tabular}

Note *: information on the revenues, expenditures of the state budget and the budget of the European funds as well as on the revenues and expenditures of the state budget, financial plans and reports on the implementation of the financial plans of governmental sub-sector units included in the Budget Act.

Source: author's own study based on www 3,4,5,6 [date of entry: 22.02.2020].

When assessing the scope of information contained in the state budget, it is worth pointing out examples of creative accounting that have a negative impact on the transparency of the state budget.

Since 2010, the budget of European funds has been treated as a financial plan separate from the "national" state budget. Earlier, all revenues from the European Union budget and other sources of foreign assistance, as well as expenditures financed with these revenues were included together with "national" revenues and expenditures in the same financial plan. In addition, the creation of a high level of specific reserves makes it very difficult to analyze the correctness of budget expenditures planning, although it increases the flexibility of implementing the state budget, e.g. in the Draft Budget Act 2020, budget reserves constitute approx. 5.3\% of planned expenditures of the "national" state budget and $38.4 \%$ of planned expenditures of the budget of European funds [Misiag, 2020, pp. 7-8].

The analysis of the state budget's revenues and expenditures without assessing its connections with other PFSE does not give a full and clear picture of the state government sub-sector finance. Therefore, the growing number of state-owned earmarked funds, especially since the level of revenues and expenditures of these funds is comparable to the revenues and expenditures of the state budget should be noted. This state of affairs negatively affects the transparency of public funds management and hinders the coordination of public administration activities and the effective management of public funds. The European Commission stated that in the draft state budget for 2020, the functioning of the expenditure rule and budgetary framework in Poland was undermined [Country Report..., 2020, p. 26]. The state budget excluded the funds for financing: the so-called thirteen pensions, social 
benefits and funeral grants, internships for medical staff, reimbursement of juvenile employees' salaries. A large proportion of these expenditures is transferred to the Solidarity Fund, which does not have its own revenues to finance these additional expenditures. This means that the fund should receive a subsidy or a loan from the state budget or from other state earmarked funds. However, the budget documents did not disclose the source of these funds or the repayment procedure of the resulting liabilities. So the practice of "pushing" the PFS`s deficit out of the state budget has returned. In addition, part of the state budget expenditure in 2020 is to be implemented by transferring treasury bonds to public universities, or TVP, free of charge, which increases the State Treasury debt.

It is also worth paying attention that since 2004, public revenues have been overestimated due to the flow of funds transferred from the state budget to the Social Insurance Fund for compensation of contributions lost to open pension funds, resulting in a more favorable picture of the state's financial situation. In recent years, this difference has been lower due to the transfer of lower funds to open pension funds (decrease in the number of members as a result of changes introduced in 2014). There also occurred a cancellation of liabilities of the social security fund to the State Treasury due to the loans granted. Describing some transfers of funds from the state budget to the Social Insurance Fund as loans, and not as subsidies, served to artificially reduce state budget expenditures and the state budget deficit.

\section{Recommendations for actions to increase the transparency of information contained in the state budget}

Information on the collection and distribution of public funds should be understandable to citizens, because transparency of information is a condition of civic education and citizens' participation in motivating politicians to manage public funds rationally. On the other hand, questions arise whether they are interested in the processes of collecting and spending public funds, the effects of these processes and their impact on the economy and society. The main reason for the low public interest in public finances in our country are the shortcomings in financial education.

Only $8-9 \%$ of respondents assess their level of financial knowledge as very good; the level of knowledge of tax issues and the tax system as well as the rules of functioning of the pension system is low [www 7]. In addition, there is a belief that citizens have no influence on the decisions of public authorities that provide them with non-transparent fiscal information. The lack of assessment of budget documents may be caused by disregard of the public under the pretext of some specialized knowledge and special interest being needed. It can be seen as a conviction about politicians and their infallibility, or it is the lack of willingness and time to prepare clear and synthetic documents by the institution. This may also result from the lack of political expertise in public finance and the lack of information transfer skills. The presented unclear, untrue data, based on political ignorance and lack of aware- 
ness, means that politicians can manipulate data on the state of public finance and thereby manipulate public opinion. This state of affairs, in the absence of interest in public funds, ensures the rulers in not taking actions to reform public finance to increase its transparency. However, citizens who are not interested in public finance or who do not have knowledge in this area bear the consequences of political decisions [Lotko, Zawadzka-Pąk, 2016, pp. 25-28].

Increasing the transparency of information contained in the state budget should be mainly ensured by: changes in the presentation of state budget expenditures in terms of functions and tasks, the consolidation of PFS and creation of a consolidated financial statement of PFS, presenting the budget to the citizen.

Changes in the manner of managing the performance-based budgeting system in the governmental sub-sector depend on the organization of planning procedures, so that the task-based system is established in accordance with the actual operating relations in the Multiannual Financial Plan of the State and the documents defining strategic development planning. It is also necessary to subordinate the expenditures plan in the budget classification system to the expenditures plan in the function and task system. It is also important to develop methods for verifying correlation between available budget funds and planned measure values of the degree of objectives achievement and for strengthening supervision over budget implementation in the task system, with the verification of the measures used to assess the degree of performance of tasks. The consolidation of PFS should consist in the liquidation of some state-owned special purpose funds, budgetary economy institutions, executive agencies, which would result in including public funds at the disposal of these entities in the state budget or local government budgets. In this case, transfers within the sector would play a smaller role (it would also be possible to reduce current expenditures), which would also increase the transparency of public finance, stability of financing sources for PFSE, and increase the pool of public funds under the direct control of law-making bodies. In practice, there is a full settlement of the state budget implementation on the basis of the annual report on the implementation of the state budget (cash accounting) and partial settlement regarding the property and financial situation of the entire PFS and the effectiveness of actions taken by PFSE, as there is no consolidated financial statement of PFS (accrual accounting). Preparation of the consolidated financial statements of PFS requires full implementation of the accruals accounting in the accounting of PFSE. As part of the consolidated financial statements of PFS, a consolidated balance sheet, a profit and loss account, a cash flow statement, and a statement of changes in the fund of PFSE should be prepared [Kostrzewa, 2011b, pp. 596-600].

Citizens should have easy access to government information. Access means not only physical access to documents (preferably collected in one place), but also their availability in a language and format that ordinary people can understand [Baran, Mikołajczyk, 2015, p. 4]. To this end, the government should design a budget for the citizen that would be accessible to people who do not have specialized knowledge about the state budget and budgeting methods. It is, therefore, necessary to develop and distribute information about the state budget in a simplified way to 
enable citizens to understand what the government is doing with their money. Of course, a budget for the citizen should not be propaganda, but it can allow the government to explain the reasons for the choices made when developing the state budget. This budget is also a way to encourage people to participate in a number of government matters. If the presentation of the budget information in this form is available and regular, it can be an invaluable tool in initiating and maintaining dialogue between the government and citizens [Petrie, Shields, 2010, pp. 3-4]. In practice, information provided to the media from the Chancellery of the Prime Minister, the Ministry of Finance, the Chancellery of the Sejm and the Chancellery of the Senate does not replace a budget for the citizen.

\section{Conclusions}

The multiplicity of organizational forms of PSFE, their diverse financial independence and various methods of accounting for the state budget, as well as the use of so-called creative accounting makes it difficult to maintain public finance discipline and has a negative impact on the level of fiscal transparency. Therefore, it is difficult to analyze the division of tasks between PFSE, financial relations between them, methods of financing them and directions of spending public funds. The problem is low transparency of the state budget, because the gradual exclusion from the state budget of various types of operations regarding the allocation of funds belonging to the Treasury makes its role in financing the tasks of the public finance sector increasingly unclear, and the budget itself is less and less associated with the financial situation of the state. Therefore, the government should create a coherent, legible and reliable message about the state finance, with particular emphasis on the state budget, which would allow every citizen to control activities in the area of fiscal policy.

\section{References}

Alt J., Drayer Lassen D., Rose S., 2006, The Causes of Fiscal Transparency: Evidence from the U.S. States. "IMF Staff Papers", vol. 53, Special Issue, pp. 1-37, https://www. $\mathrm{imf}$. org/external/np/res/seminars/2005/arc/pdf/alt.pdf [date of entry: 22.02. 2020].

Baran J., Mikołajczyk K., 2015, Ja udostepniać obywatelom dane o finansach publicznych, IBS, Kwiecień, https://ibs.org.pl/publications/jak-udostepniac-obywatelom-dane-ofinansach-publicznych [date of entry: 22.02.2020].

Country Report Poland 2020, 2020, European Commission, Commission Staff Working Document, https://ec.europa.eu/info/sites/info/files/2020-european_ semester_ country-report-poland_pl.pdf [date of entry: 28.02.2020].

Jabłoński M., 2018, Jawność driatania władz, publicznych jako dobro wspólne, „Ruch Prawniczy, Ekonomiczny i Socjologiczny", nr 80(1), s. 39-52, DOI: 10.14746/rpeis. 2018.80.1.5. 
Kopits G., Craig J., 1988, Transparency in Government Operations, IMF Occasional Paper 158, https://www.imf.org/external/pubs/ft/op/158/op158.pdf [date of entry: 22.02.2020].

Kostrzewa T., 2011a, Odpowiedzialność spoteczৃna rz̨adu na tle sprawozdawczości budizetowej i finansowej sektora finansów publicznych w Polsce, „Zeszyty Naukowe Uniwersytetu Szczecińskiego", nr 32, s. 237-252.

Kostrzewa T., 2011b, Wdrożenie skonsolidowanego sprawozdania finansowego sektora finansów publicznych w Polsce, „Zeszyty Naukowe Uniwersytetu Szczecińskiego. Finanse. Rynki Finansowe. Ubezpieczenia", nr 41, s. 595-605.

Kozłowska A., 2018, Próba identyfikacji podstawonych czynnikón determinujacych jakość sprawozdan finansowych, „Prace Naukowe Uniwersytetu Ekonomicznego we Wrocławiu", nr 503, s. 246-258, DOI: 10.15611/pn.2018.503.22.

Lotko E., Zawadzka-Pąk U.K., 2016, Moralność, przejraystosíc i edukacja jako determinant optymalnego nydatkowania środkón publicznych, „Prawo Budżetowe Państwa i Samorządu”, nr 4(4), s. 21-34, DOI: 10.12775/PBPS.2016.021.

Malinowska-Misiag E., 2016, Wprowadzenie do problematykei jawności i przejraystości finansów publicznych [w:] Jawność i przejraystość finansón publicznych Malinowska-Misiag E. (red.), Oficyna Wydawnicza Szkoła Główna Handlowa w Warszawie, Warszawa.

Misiąg W., 2020, Opinia o ustawie budizetowej na 2020 rok, Kancelaria Senatu, Opinie i ekspertyzy OE-282, Warszawa, https://www.senat.gov.pl/gfx/senat/pl/senatekspertyzy/5462/plik/oe-285.pdf [date of entry: 03.03.2020].

Misiag W., Niedzielski A., 2001, Jawność i przejryystość finansów publicznych w Polsce w świetle standardów Miedzynarodowego Funduszu Walutowego, IBnGR, Warszawa.

Nowak W.A., 2004, Rachunkowość sektora publicznego - koncepcje, metody, uwarunkowania, Wydawnictwo Naukowe PWN, Warszawa.

Petrie M., Shields J., 2010, Producing a Citizens' Guide to the Budget: Why, What and How?, "OECD Journal on Budgeting", vol. 2, pp. 1-14, http://internationalbudget.org/wp-content/uploads/Producing-a-Citizens-Guide-to-the-Budget.pdf [date of entry: 22.02.2020].

Sawulski J., 2015, Audyt (nie)przejryystości finansów publicznych w Polsce, IBS Policy Paper, no. 02, https://ibs.org.pl/app/uploads/2016/01/IBS_Policy_Paper_02_2015_ pol.pdf [date of entry: 22.02.2020].

Zapewnienie jawności i przejraystości finansów publicznych przez system sprawozdanczości finansowej, 2015, Najwyższa Izba Kontroli, Warszawa, https://www.nik.gov.pl/ plik/id,11507,vp,13857.pdf [date of entry: 22.02.2020].

www 1, https://www.gov.pl/web/finanse/akty-prawne [date of entry: 22.02.2020]. www 2, https://www.nik.gov.pl/kontrole/analiza-budzetu-panstwa/ [date of entry: 20.02.2020].

www 3, https://www.gov.pl/web/finanse/wieloletni-plan-finansowy-panstwa-nalata 2019-2022 [date of entry: 20.02.2020].

www 4, https://www.gov.pl/web/finanse/budzet-na-2020 [date of entry: 20.02. 2020]. 
www 5, https://www.gov.pl/web/finanse/sprawozdanie-roczne-za-2018 [date of entry: 22.02.2020].

www 6, http://prawo.sejm.gov.pl/isap.nsf/DocDetails.xsp?id=WDU20190000198 [date of entry: 20.02.2020].

www 7, https://www.gpw.pl/pub/GPW/files/PDF/Poziom_wiedzy_finansowej_ Polakow_2019.pdf [date of entry: 22.02.2020]. 